6. Гриншпун Б.М., Шаховская С.Н. Алалия. Логопедия. учебник для студ. дефектол. фак. пед. высш. учеб. Заведений. М.: Гуманитар. изд. центр. ВЛАДОС, 2008. 703 с.

DOI https://doi.org/10.30525/978-9934-26-173-2-55

\title{
АВТОМАТИЗАЦІЯ ЗВУКІВ МОВЛЕННЯ У ДОШКІЛЬНИКІВ ЗАСОБАМИ ЕЙДЕТИКИ
}

\author{
Костик Л. Б. \\ кандидат філологічних наук, \\ асистент кафедри педагогіки та психології дошкільної освіти \\ Чернівецький національний університет імені Юрія Федьковича \\ Палагнюк О. В. \\ кандидат психологічних наук, \\ асистент кафедри педагогіки та психології дошкільної освіти \\ Чернівецький національний університет імені Юрія Федьковича \\ м. Чернівиі, Україна
}

Своєчасне засвоєння правильної вимови фонем, формування вміння контролювати їхню вимову у процесі спілкування з оточуючими - одна 3 вагомих запорук повноцінного розвитку дитини. Різні відхилення у розвитку фонетичного боку мовлення викликають у дітей комплекс труднощів: у процесі адаптації їх у соціальне середовище, особливо нове, незвичне для них; під час навчання, особливо при опануванні навичками письма та читання; при спілкуванні 3 дорослими та дітьми. Порушення звуковимови часто $\epsilon$ причиною формування у них комплексів неповноцінності, вони також можуть у майбутньому гальмувати їхню професійну самореалізацію. Усі ці причини вагомі для того, щоби своєчасно виявляти такі відхилення у розвитку дитини i виправляти їх.

Мовлення інтенсивно розвивається в дошкільному віці і подолання його вад у цей період відбувається швидше і легше. Саме в дошкільному дитинстві мовлення не лише стає окремим і регульованим пізнавальним процесом, а й інтегрується та диференціюється 3 іншими вищими психічними функціями, свідченням чого є формування мовленнєвої діяльності, прямо не пов'язаної з практичними діями. Дошкільник учиться правильно вимовляти та розрізняти звуки рідної мови, з опорою 
на свій чуттєвий і практичний досвід збагачує словник, експериментує зі словами, оволодіває парадигмою граматичних форм, навчається звукового, складового, морфемного та синтаксичного аналізу.

Отже, процес формування мовленнєвої діяльності відбувається довготривало i поступово, разом із фізичним зростанням та психофізичним розвитком дитини. Рівень розвитку розумових здібностей дошкільників чимало важить для успішного оволодіння ними програмним матеріалом. Розвивальний ефект навчання залежить від того, які знання повідомляються дітям і в який спосіб. Зокрема, такі відомі вчені, як: О. Запорожець, А. Усова, Н. Поддьяков, довели необхідність прямого керування з боку дорослих розвитком розумових здібностей дітей. 3 цією метою вони радять у процесі навчальновиховної роботи послуговуватися різноманітними символами, знаками, замінниками, наочним моделюванням (схемами, планами, кресленнями)[2].

Застосування образів-символів мовних звуків у корекційній роботі 3 дітьми дає змогу повніше використовувати резерви розумового розвитку дитини, а також створювати належне навчально - розвивальне середовище. Педагогічна технологія 3 опорою на образи-символи (за М. Фомичовою) передбачає не лише формування відповідних артикуляційних навичок, а й саморозвиток, самоконтроль, самокорекцію вад вимови звуків; перехід від активності дорослого до активності самої дитини [1].

Завдяки використанню образів-символів логопед може уникати мовно-корекційного тиску на дитину, щоб не пригнічувати іiі. Оперування символами наближує дитину до природного, а не штучно-примусового вимовляння звуків, створює безпосередні передумови для самостійної корекції їх, для звукового самовдосконалення. До того ж символізація наочного матеріалу дає змогу коригувати не лише якийсь один звук, а кілька звуків водночас [3].

Внаслідок вікової недорозвиненості аналітико-синтетичної діяльності мозку (мовні центри Брока та Верніке у лобній ділянці лівої півкулі мозку), дитина ще не здатна належним чином порівнювати свою неправильну звуковимову з правильною. У такій ситуації самоконтроль $\epsilon$ недостатнім або взагалі відсутній. I саме символи самоорганізовують, налаштовують дітей на правильну звуковимову, скорочують термін виправлення мовленнєвих вад.

Роботі логопеда 3 дітьми допомагає символізація звуків. Орієнтуючись на пропоновані символи, діти запам'ятовують не лише сам звук, а й образ, що виникає в їхній уяві, коли вони вимовляють цей звук. Таке запам'ятовування 3 опорою на образ називається ейдетичним. Це 
особливий різновид образної пам'яті, здатність найбільш яскраво й точно відтворювати в усіх деталях наочні образи предметів через тривалий час. Характерною для ейдетизму $\epsilon$ емоційна забарвленсть образів[5].

Засновник ейдотехніки Е. Йєнш (Марбурзька психологічна школа (Німеччина) стверджував, що ейдетизм $\epsilon$ закономірною стадією дитячого розвитку [7]. Саме цю закономірність дитячого розвитку ми взяли за основу, розробляючи методику використання образних символів звуків (літер) у логопедичний роботі з дітьми дошкільного віку. Спочатку дитина навчається правильно вимовляти звук із допомогою дорослого та певного образу-символу; потім спирається лише на символ; а згодом обходиться вже без нього. На початковому етапі автоматизація звука за допомогою символу відбувається на рівні механічного засвоєння, а з часом поступово переходить на рівень свідомого використання знань та навичок [6].

Дитині значно легше засвоїти поняття, коли воно не тільки показане логопедом на собі, а й позначене зрозумілим, близьким для дитини образом, легким для сприймання. Використання символів на всіх етапах роботи дає можливість активізувати всі види аналізаторів, а це набагато пришвидшує навчальний процес [8].

У своїй роботі ми використовуємо такі види символів: символ - орган артикуляції; символ - артикуляційна позиція; символ - звук: символ артикуляційна вправа. При використанні символізації в навчальному процесі у дітей немає проблем зі звуковим аналізом. Дитина усвідомлює поняття «звук», не зливає, як це зазвичай буває, приголосний з голосним. Символ - артикуляційна позиція використовується тільки на заняттях 3 постановки звуків та автоматизації. Спочатку на основі символів використовуємо артикуляційні комплекси постановки в поєднанні 3 дидактичними іграми для розвитку фонематичного слуху. Основне завдання - навчити чітко виділяти потрібний звук і знати його правильну артикуляцію.

До структури заняття входить: 1. Розминка - комплекс постановки звуку, наприклад: -Ш-. На підставці ставимо символи - звуки -Ш- та C- (дитина не вимовляє шиплячих); 2. Проводиться дидактична гра «Яку пісеньку я співаю?», «Заспівай мені пісеньку»; 3. Вивчення правильної позиції мовних органів для вимови -Ш-. На підставку виставляємо символ - позиція зубів та губ. Символ - позиція язика. Символи знайомі з попередньої роботи. Нові вивчаються на занятті; 4. Дитині пропонуємо за символами виконати артикуляційну позицію; 
5. Вводимо новий символ - «Теплий подих», яким перевіряємо правильність звука -Ш-; 6. Коли ізольований звук поставлено, виконуємо завдання з диференціації.

Отже, використання символів у корекційній роботі створює відповідне предметно-стимулююче середовище, яке забезпечує формування сенсомоторної цілісності дітей (емоційності, інтелекту, волі), підтримує єдність думки, почуттів і дій. Крім того, символи породжують творчий потенціал, збільшують зацікавлення, розвивають мотивацію, сприяють кращому засвоєнню корекційно-навчального матеріалу, підводять до самостійного засвоєння дітьми норм правильної вимови звуків рідної мови.

\section{Література:}

1. Андросова В. Ейдетика і формування правильної вимови звуків. Палітра педагога. 2007. № 3. С. 27-29.

2. Беседіна А. Вплив методів і завдань ейдетики на розвиток особистості дитини. Рідна школа. 2009. № 2-3. С. 61-62.

3. Білуха В. В. Ейдетика на допомогу логопеду. Логопед. 2011. № 12. C. 23-29.

4. Васько А. М. Ейдетика для дошкільнят: програма розвитку пізнавальної активності дошкільників методами ейдетики. Обдарована дитина. 2013. № 4. С. 51-59.

5. Верещак Л. Б. Розвиваємо мовлення дітей дошкільного віку засобами ейдетики. Логопед. 2017. № 9. С. 30-32.

6. Денега 3. Д. Використання ейдетичних символів під час формування фонематичної компетентності дошкільників із ФФНМ. Логопед. 2017. № 8. C. 5-8.

7. Роменець В. А., Маноха І. П. Ейдетичний напрям у психології. Е. Йєнш. Історія психології XX століття: навчальний посібник. Київ: Либідь, 1998. С. 233-236.

8. Пащенко О. Ейдетика в навчанні. Дошкільне виховання. 2010. № 5. C. 20-21. 